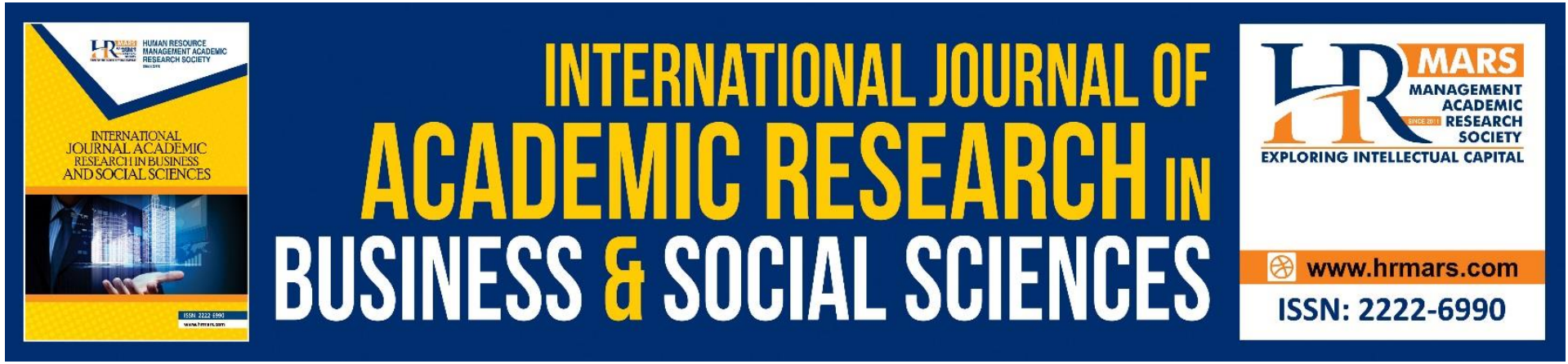

\title{
Determinants of Consumer's Willingness to Purchase Online in Malaysia: The Role of GEN Z's Attitude
}

Edward Probir Mondol, Narjes Ahmed Salman, Abu Obida Rahid, Asif Mahbub Karim

To Link this Article: http://dx.doi.org/10.6007/IJARBSS/v11-i7/10460

DOI:10.6007/IJARBSS/v11-i7/10460

Received: 14 May 2021, Revised: 16 June 2021, Accepted: 28 June 2021

Published Online: 10 July 2021

In-Text Citation: (Mondol et al., 2021)

To Cite this Article: Mondol, E. P., Salman, N. A., Rahid, A. O., \& Karim, A. M. (2021). Determinants of Consumer's Willingness to Purchase Online in Malaysia: The Role of GEN Z's Attitude. International Journal of Academic Research in Business and Social Sciences, 11(7), 368-385.

Copyright: @ 2021 The Author(s)

Published by Human Resource Management Academic Research Society (www.hrmars.com)

This article is published under the Creative Commons Attribution (CC BY 4.0) license. Anyone may reproduce, distribute, translate and create derivative works of this article (for both commercial and non-commercial purposes), subject to full attribution to the original publication and authors. The full terms of this license may be seen at: http://creativecommons.org/licences/by/4.0/legalcode

Vol. 11, No. 7, 2021, Pg. 368 - 385

Full Terms \& Conditions of access and use can be found at http://hrmars.com/index.php/pages/detail/publication-ethics 


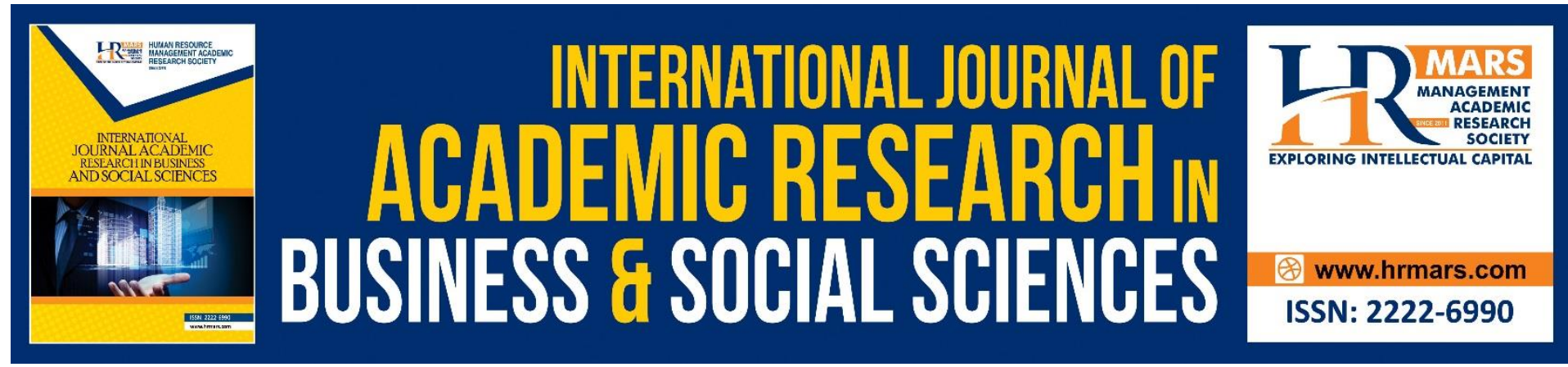

\title{
Determinants of Consumer's Willingness to Purchase Online in Malaysia: The Role of GEN Z's Attitude
}

\author{
Edward Probir Mondol ${ }^{1}$, Narjes Ahmed Salman², Abu Obida \\ Rahid $^{3}$, Dr. Asif Mahbub Karim ${ }^{4}$ \\ ${ }^{1}$ Principal and Chief Learning Evangelist, Global Academy of Holistic Leadership and \\ Coaching Inc, Canada, '2Lecturer, English, English Language Center, University of Bahrain, \\ ${ }^{3}$ Lecturer, Faculty of Business Administration, CCN University of Science \& Technology, \\ Kotbari, Cumilla, Bangladesh, ${ }^{4}$ Professor and Dean Binary Graduate School, Binary \\ University, Malaysia
}

\begin{abstract}
The progress of the World Wide Web has led to a new form of e-tailing or internet shopping for retail purchases. Since then, consumer behaviour has become a core factor in online purchases. The determinants of internet orders for consumers should then be taken into account. This paper examines factors which influence the intention of Gen $Z$ to purchase online on a platform. What factors drive Gen $Z$ to purchase online? In order to find this finding, a survey of 315 respondents who resided in Kuala Lumpur in Malaysia was used. Specifically, researchers investigated the relationship between perceived usefulness, perceived ease of use and prior online purchase experience with intention to purchase online. Then, researchers investigated the mediation role of attitude between perceived usefulness, perceived ease of use and prior online purchase experience with intention to purchase. Data confirms that a positive and significant relationship is found between perceived usefulness and perceived ease of use with intention to purchase. Furthermore, a positive and significant relationship is not found between prior online purchase experience and intention to purchase online. Besides, this study claims that attitude mediates the relationship between perceived ease of use and prior online purchase experience with intention to purchase. Smart PLS 3.0 was used to analyse the results following in the quantitative approach. This result shows that eplatform was an effective marketing method for new customers in the younger generation. It also demonstrates that the cyber world plays an important role in digital commercialization making the penetration of consumers faster and easier for brands.
\end{abstract}

Keywords: Online Purchase Intention, Gen Z, Attitude, SEM, Malaysia

\section{Introduction}

In recent days, online shopping is becoming more common among young generations with the advent of new technology. The younger generation is more likely to shop online, because its life becomes easier and more relaxed (Ghouri et al., 2017; Mohseni et al., 2018). Since smartphones are available, they get quick Internet access and purchase their favourite items 
from online shops. If an outbreak occurs in the country, online shopping offers the rights that retailers or their approved shipping partners deliver the goods home (Hossain et al., 2018). In the last few days, the spread of COVID-19 worldwide has been catastrophic (Hossain et al., 2020). This contagious infection has forced us to stay at home. Most countries all over the world have been locked or regulated by campaign to avoid this infectious virus spreading to their fellow people, therefore; people should remain indoors. You cannot move from the house as COVID-19 is spontaneously spreading. People then use the internet to purchase their goods from online shops, particularly at younger generations (Alavi et al., 2016; Chi, 2018; Bhattacharjee et al., 2020).

Online shopping is generally a kind of electronic company that allows purchasers to buy goods from retailers directly over the Internet (San et al., 2020; See-To \& Ho, 2014; Mohmed et al., 2016). If buyers need to shop on the site, they would have access to and understanding of the Internet. If the foundation is ready, the Internet can allow customers to easily access information and quickly shop for convenience from their geographical location 24 hours a day 7 days a week (Escobar-Rodríguez \& Bonsón-Fernández, 2017; Polas et al., 2018a; Dapas et al., 2019). In addition, online consumers are younger than traditional customers. While older generations are still higher than ever, young people overwhelm the online population despite all. In addition to the fact that they are more familiar with Internet e-commerce than their older generations, according to Kim and ammeter (2008), they are also processing website details five times faster. Gen Z refers to the same generation of age born after 1995 (Mohammed, 2018; Hossain et al., 2018; Youn, 2009). This generation is technologically knowledgeable, since in the information period they endured adolescence and were inclined to use the media every day. It is the largest number of people who use the internet as a shopping platform (Dedeke, 2016; Bhattacharjee et al., 2018; Dapas et al., 2019). This paper mainly aims to find out the Z GEN's online purchases of COVID-19 in Malaysia. This paper confirmed that perceived usefulness and perceived ease of use directly influence on the intention to purchase of Z GEN. This paper also confirmed that attitude mediates the relationship between perceived ease of use and prior online purchase experience with intention to purchase online.

\section{Literature Review and Hypothesis Development}

\section{Perceived Usefulness and Intention to Purchase Online}

Researchers believe in the first hypothesis that perceived usefulness influences their intention to purchase online. The belief that use of the latest technologies can upgrade or boost efficiency is indicated by a human (Wu \& Cheng, 2018). With respect to online shopping, use is an indication of the extent to which buyers believe that the use of the Internet is an enhanced success or efficiency (Polas et al., 2017; Yulianita, 2018; Hossain et al., 2020). The results of the shopping experience show perceived usefulness (Bashir et al., 2020; Fu et al., 2018). In addition the most important advantages of online shopping for young generations are daily comprehensive details, flexibility and speed as well as access to cheap and easy orders (Moslehpour et al., 2018). The simplicity and pace of shopping can be truly useful for experienced internet users who are stuck in during traditional shopping hours. Also, Zhang et al. (2017) found that an online music webpage perceived usefulness is a key predictor of young generation respondents' purchasing intention during their research. The ease of use of technologies makes life simple and convenient for people during the COVID-19 epidemic. You can buy food online from your home website. You can also buy your items from online stores which mean that you are buying without touching. It also allows young generations to 
purchase online, without virus contamination, in particular COVID-19. The perceived usefulness of young generations simplifies and facilitates their view of the environment. For those that came into being in the 1990s, the perceived usefulness is high (Joo et al., 2018). Past investigators have cleared the building for $\mathrm{PU}$ and the purpose of future Internet customers has been identified (Driediger \& Bhatiasevi, 2019). In all the colossal support from various other technical applications, the studies on internet retailing from a TAM perspective are limited, and PU builds. For example, Yang et al. (2016) have confirmed that the intention in the media is having a positive effect by PU. PU also influences the online buying intention of people significantly and positively, especially between younger generations (Cho \& Sagynov, 2015; Lim et al., 2016; Bonn et al., 2016; Abdullah et al., 2017; Polas et al., 2018a Dhahak \& Huseynov, 2020). Thus, we hypothesize that,

H1: There is a positive and significant association between individual's perceived usefulness and their intention to purchase online.

\section{Perceived Ease of Use and Intention to Purchase Online}

In the second hypothesis, authors assumed that perceived ease of use has an effect on intention to purchase online. Generally, perceived ease of use refers to how simple navigating Web pages, Internet features and the Web interface is to the point of an individual becoming aware of a specific technology (Cho \& Sagynov, 2015; Moslehpour et al., 2018; Polas \& Afshar Jahanshahi, 2020). It deals with the technical elements considered as important (Ashraf et al., 2016; Polas et al., 2018b). More simply, since it is most likely endorsed by internet consumers, a technology is more favourable than any other. In other words, the more complex a technical usage is, the more likely the website is to be used. PEOU and PU are technological acceptability attributes (Ozturk et al., 2016; Polas et al., 2020). The PEOU build was used in numerous contexts, including electronic mail, e-commerce and $\mathrm{m}$-commerce (Hansen et al., 2018; Suleman \& Zuniarti, 2019).

The perceived ease of use is described as the impression of the user that new technology is effortless (Visinescu et al., 2015; Lee et al., 2017). This background refers to user expectations that shopping on the Internet would require a minimum of efforts. Ease of use refers to online shopping (Hess et al., 2014; Polas \& Raju, 2021). If the perceived utility refers to the consumer's views on the result of the online shop experience, the perceived ease of use refers to their expectations of the mechanism leading to the final online shopping result. In short, how convenient shopping on the Internet is for users is to fulfil their tasks and how simple it is to use the Internet as a means of shopping (Rehman et al., 2019). The TAM states that the perceived ease of use has a dual impact on user intention of shopping online, both directly and indirectly. Indirect impact on purpose is considered to be beneficial as it is easy to use technologies (Ma et al., 2017; Hanjaya et al., 2019).

Furthermore, PEOU is seen as one of the growth drivers in the smartphone industry. PEOU could positively impact the PU of mobile business (Septiani et al., 2017; Polas et al., 2021). Wang et al. (2020) find that in mobile commerce PEOU is a good indicator of PU, and similarly Raza et al. (2017) contend that the PEOU, PU and consumer loyalty association in the online shopping world exists positively. Online businesses need to be more focused on friendliness and the provision of a user-friendly Website, according to Yahia et al. (2018). The role of PEOU in terms of consumer retention and general loyalty has been explored by most academics. The adoption of mobile services can be explained by advice to users and help and user skills. Thus, we hypothesize that, 
$\mathrm{H} 2$ : There is a positive and significant association between individual's perceived ease of use and their intention to purchase online

\section{Prior Online Purchase Experience and Intention to Purchase Online}

In the third hypothesis, authors expect that prior online purchase experience has an effect on intention to purchase online. The response of a person to a judicial task depends in general on three points of view, the complete meaning, history or stimulation of the individual's past experiences (Ponte et al., 2015; Balakrishnan \& Griffiths, 2018). Web shopping with a large number of customers is a moderately new action, internet purchases are currently considered more dangerous than earthly purchases (Lee \& Lee, 2015; Polas et al., 2018b). Moreover, online customers depend intensively on experiential efficiency, on which the quality of their experience can be achieved only through previous buying experience. Prior experience would have a strong effect on subsequent behaviour. The younger generation is keener to use their online form to buy things, saving time and effort (Chang \& Chao, 2018; Fazal-e-Hasan et al., 2018). It also helps guard against contamination during the likely COVID-19 international outbreak. In the sense of web shopping, young shoppers will evaluate their experience of online shopping as regards product data, payment methods, distribution conditions, service offerings, risks involved, anonymity, safety, personalization, visual appeal, navigation, entertainment and enjoyment (Khaled et al., 2019; Moreno et al., 2017; Rajesh, 2018; Rafsandjani, 2018).

In addition, consumer experience with the Internet fuels internet shopping creation (Siamagka et al., 2016). In addition, shoppers with high online purchasing intentions generally have previous buying experience to help reduce their vulnerabilities (De la Llave et al., 2019). Moreover, after seeing them, young customers can only purchase goods from the Internet. In addition, customers with earlier online buying experience are bound to shop online than those who need that knowledge. Silva et al. (2018) clarify this wonder by increasing individual expertise of online buying, perhaps with small buys from the very beginning, and by building certainty and abilities that promote the gradual purchase of the Web. With the enormous literature it is very likely that the online purchasing experience of the consumer will have profound effects on your potential online shopping intentions (Akar \& Nasir, 2015; Ponte et al., 2015; Oghazi et al., 2018). Thus, we hypothesize that,

H3: There is a positive and significant association between individual's prior online purchase experience and their intention to purchase online.

\section{The Mediation Role of Attitude}

Attitude is considered one of the major determinants of advertisement productivity. The thought or object is used as an aggregate feeling or assessment (De Cock et al., 2014). This description implies that perceptions shift over time, when persons learn from various sources about the concept or thing. In this analysis we regard attitude as an overall feeling of internet ads in general, while attitude is the overall feeling for a specific brand. Attitude is the general feeling. Nam et al. (2019) suggested, While web advertising is more favourable, people have more favourable attitudes towards the ad banner overall. The behaviours, as proposed by reasoned action theory, play an important role in deciding his/her motives of behaviour (Wan $\&$ Shen, 2015). Moreover, previous analysis has demonstrated that the effects of promotional messages are potentially influenced by publicity and brand behaviour (Kaushal \& Kumar, 2016). Different researches on the online environment have identified the mediating role of 
attitudes in the relationship between website encouragement and desire to buy online (Shaouf et al., 2016; Redondo \& Aznar, 2018; Hameed \& Qayyum, 2018).

The attitude of the customer online through the online shopping channel is either positive or negative as an appraisal outcome. So if the buyer has such a good outlook, please, the customer intends to buy online. Any future customers may be optimistic about online shopping, but some of its partners may be pessimistic. In keeping with López-Bonilla \& LópezBonilla (2017) model of technical adoption, the attitude is mediated by variables (perceived usefulness and perceived ease of use). This model has however been recreated by deleting the attitude component (Altawallbeh et al., 2015). The social and psychological properties of consumers are largely drawn from psychological theories such as TPB (Ogiemwonyi et al., 2020). The consumer's e-shopping intention and real use (Fraustino et al., 2018; Kwol et al., 2020 Koththagoda \& Herath, 2018) are positively linked to favourable attitudes towards shopping.

H4: Attitude mediates the relationship between individual's perceived usefulness and their intention to purchase online.

H5: Attitude mediates the relationship between individual's perceived ease of use and their intention to purchase online.

H6: Attitude mediates the relationship between individual's prior online purchase experience and intention to purchase online.

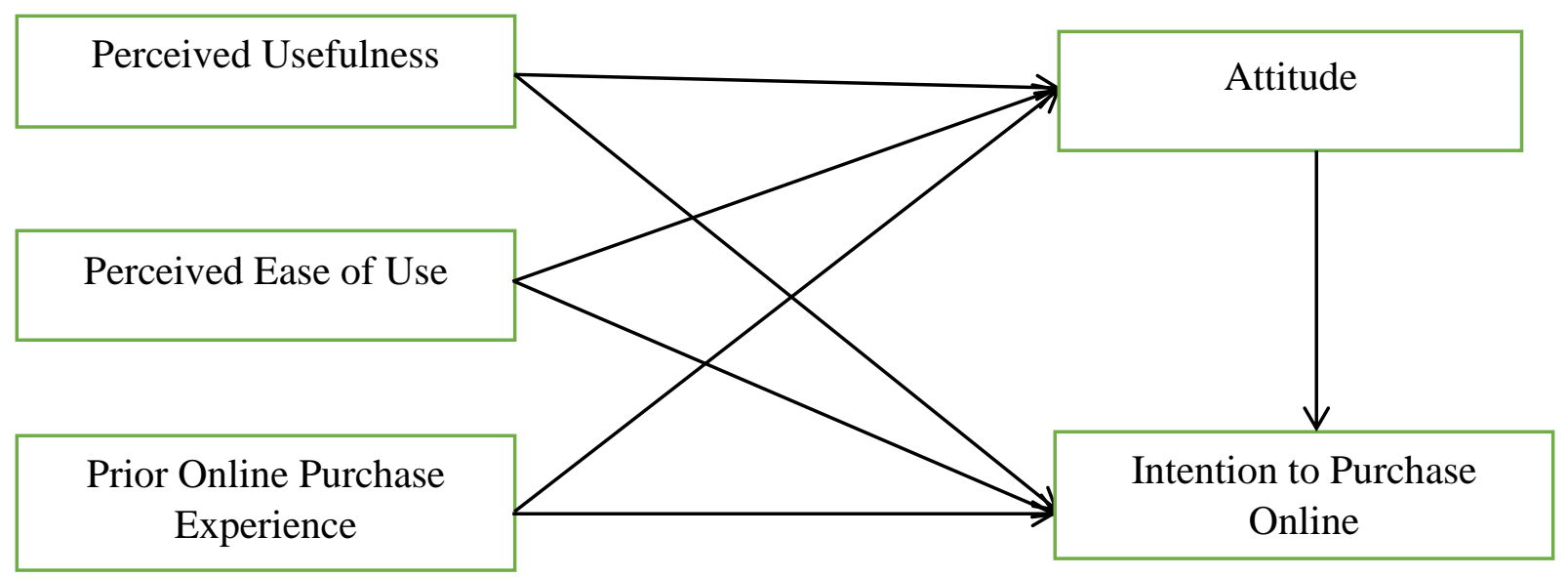

Figure 1: The Framework of the study

\section{The Methodology of the Study}

Positivist research approach was adopted following hypothetical deductive observational method (Polas \& Raju, 2021). Stratified sampling technique was used following cross-sectional study. Researchers collected the primary data using survey method. The survey questionnaire was the main source of collecting data. Researchers have randomly selected 315 GEN Z respondents, who were staying at Kualalumpur in Malaysia during COVID-19 outbreak. These respondents were between 18 and 25 years old (young generation). The data was collected using a well-prepared questionnaire sent to 500 consumers through email, whatsapp message, Facebook message and with the help of friends, colleagues, and received 315 usable and complete responses. Smart PLS 3.0 was used to run the SEM (Structural Equation Modelling) for assessing the research model. 


\section{Measurement}

\section{Perceived Usefulness}

Here, researchers have used three items adopted from Van der Heijden et al. (2003) for measuring the perceived usefulness. These items are "The online purchasing process on this website is fast, it is easy to purchase online on this website, and the interactions with the website are clear and understandable". The reliability assessment resulted in a Cronbach's alpha of 0.864 for this three-item perceived usefulness scale.

\section{Perceived Ease of Use}

Here, researchers have used three items adopted from Amin et al. (2014) for measuring the perceived ease of use. These items are "Learning to use this mobile site is easy, Becoming proficient in using this mobile site is easy, and overall, this mobile site is easy to use". The reliability assessment resulted in a Cronbach's alpha of 0.789 for this three-item perceived ease of use.

\section{Prior Online Purchase Experience}

Here, researchers have used three items adopted from Ling, Chai and Piew (2010) for measuring the prior online purchase experience. These items are "I am experienced with the use of the web site, I feel competent of using the web site, and I feel that the web site is easy to use". The reliability assessment resulted in a Cronbach's alpha of 0.789 for this three-item prior online purchase experience scale.

\section{Attitude}

Here, we have used four items adopted from Vazquez and Xu (2009) for measuring the attitude. These items are "I am interested in online shopping, I think online shopping is easy to use, I feel comfortable with online shopping, and My attitude towards online shopping is positive". The reliability assessment resulted in a Cronbach's alpha of 0.822 for this four-item attitude scale.

\section{Intention to Purchase Online}

Here, we have used four items adopted from Ling, Chai and Piew (2010) for measuring the online purchase intention. These items are "It is likely that I will transact with this web retailer in the near future, Given the chance, I intend to use this retailer's web site, Given the chance, I predict that I should use this retailer's web site in the future, and The web site of this webretailer keeps my best interests in mind.". The reliability assessment resulted in a Cronbach's alpha of 0.822 for this four-item online purchase intention scale. 
INTERNATIONAL JOURNAL OF ACADEMIC RESEARCH IN BUSINESS AND SOCIAL SCIENCES

Vol. 11, No. 7, 2021, E-ISSN: 2222-6990 @ 2021 HRMARS

Findings

Table 1: Respondent's Demographic Profile

\begin{tabular}{|c|c|c|c|c|c|}
\hline Characteristics & Frequency & Percentage & Characteristics & Frequency & Percentage \\
\hline \multicolumn{3}{|c|}{ Gender } & \multicolumn{3}{|c|}{ Education Level } \\
\hline Male & 203 & 64.44 & Elementary school & 44 & 13.97 \\
\hline Female & 112 & 35.56 & Junior high school & 105 & 33.33 \\
\hline \multicolumn{3}{|c|}{ Age } & $\begin{array}{l}\text { High school or } \\
\text { vocational school }\end{array}$ & 145 & 46.03 \\
\hline 18-19 Years & 77 & 24.44 & $\begin{array}{l}\text { College or university } \\
\text { education }\end{array}$ & 21 & 6.67 \\
\hline 20-21 Years & 89 & 28.25 & \multicolumn{3}{|c|}{ Monthly Income (US Dollar) } \\
\hline 22-23 Years & 98 & 31 & $250-500$ & 175 & 55.56 \\
\hline \multirow[t]{2}{*}{ 24-25 Years } & 51 & 16.19 & $501-750$ & 54 & 17.14 \\
\hline & & & $751-1000$ & 49 & 15.56 \\
\hline \multicolumn{3}{|c|}{ Marital Status } & $1001-1250$ & 23 & 7.30 \\
\hline Single & 239 & 75.87 & 2501 or above & 14 & 4.44 \\
\hline Married & 66 & 20.95 & & & \\
\hline Divorced & 10 & 3.17 & & & \\
\hline
\end{tabular}

The above table 1 indicates the respondents' demographic profile. A sample of 315 Malaysian respondents was used for getting the study outcomes. As seen in Table 1, 64.44 per cent of respondents were male and 35.56 per cent of respondents were female. After that, 24.44 per cent of respondents were between the ages of 18-19 years, 28.25 per cent of respondents were between the age of 20-21 years, 31 per cent of respondents were between the age of 22-23 years, 16.19 per cent of respondents were between the age of 24-25 years. Moreover, 75.87 per cent of respondents were single and 20.95 per cent of respondents were married. 13.97 per cent of the respondents hold Elementary school degree, 105 per cent of the respondents hold Junior high school degree, 46.03 per cent of the respondents hold High school or vocational school degree and 6.67 per cent of the respondents hold College or university education degree. Finally, 55.56 per cent of respondent's monthly income was between 250-500 USD, 17.14 per cent of respondents' monthly income was between 501750 USD, 15.56 per cent of respondents' monthly income was between 751-1000 USD, 7.30 per cent of respondents' monthly income was between 1001-1250 USD and 4.44 per cent of respondents monthly income was between 2501 or above USD. 
INTERNATIONAL JOURNAL OF ACADEMIC RESEARCH IN BUSINESS AND SOCIAL SCIENCES Vol. 11, No. 7, 2021, E-ISSN: 2222-6990 @ 2021 HRMARS

\section{Measurement of Model Assessment}

Table 2: Measurement of Model Assessment

\begin{tabular}{|c|c|c|ccc|c|}
\hline & & Loading & & & & R- \\
& Items & & AVE & CR & Alpha & Square \\
\hline \multirow{3}{*}{ Perceived Usefulness (PU) } & PU1 & 0.767 & & & & \\
& PU2 & 0.747 & 0.643 & 0.843 & 0.718 & \\
& PU3 & 0.884 & & & & \\
\hline \multirow{3}{*}{ Perceived Ease of Use (PEU) } & PEU1 & 0.926 & & & & \\
& PEU2 & 0.73 & 0.736 & 0.892 & 0.815 & \\
& PEU3 & 0.903 & & & & \\
\hline \multirow{3}{*}{ Prior Online Purchase Experience } & POPE1 & 0.949 & & & & \\
(POPE) & POPE2 & 0.890 & & & & \\
& POPE3 & 0.945 & & & & \\
\hline \multirow{2}{*}{ Attitude (A) } & A1 & 0.770 & & & & \\
& A2 & 0.923 & 0.706 & 0.905 & 0.859 & 0.895 \\
& A3 & 0.811 & & & & \\
& A1 & 0.849 & & & & \\
\hline \multirow{3}{*}{ Intention to Purchase Online } & IPO1 & 0.849 & & & & \\
& IPO2 & 0.828 & & & & \multirow{2}{*}{0.949} \\
& IPO3 & 0.867 & 0.717 & 0.911 & 0.868 & 0.916 \\
& IPO4 & 0.842 & & & & \\
\hline
\end{tabular}

Table 2 confirms that AVE value of every variable is above 0.50 and the value of $C R$ and Cronbach's Alpha is above 0.70 and the value of factor loadings is above 0.60 which are the suggested or accepted range. Here, intention to purchase online is demonstrated by large effect $(0.916$ or $0.916 \%)$ with independent variables. Then, attitude is also stated by $(0.895$ or $89.5 \%$ ) large effect with independent variables.

Table 3: Predictive Relevance

\begin{tabular}{|l|c|c|c|}
\hline \multicolumn{1}{|c|}{ Constructs } & Attitude & $\begin{array}{c}\text { Intention to Purchase } \\
\text { (f2) }\end{array}$ & $\mathbf{Q}$ \\
\hline Attitude & & 0.081 & 0.487 \\
\hline Intention to Purchase Online & & & 0.499 \\
\hline Perceived Ease of Use & 0.353 & 0.364 & 0.451 \\
\hline Perceived Usefulness & 0.063 & 0.308 & 0.301 \\
\hline $\begin{array}{l}\text { Prior Online Purchase } \\
\text { Experience }\end{array}$ & 0.458 & 0.000 & 0.632 \\
\hline
\end{tabular}

Large effect > 0.34; Medium effect $>0.14$; Small effect $>0.01$ (Cohen, 1988)

Table 3 shows that attitude has a small effect on intention to purchase online. Then, perceived ease of use has a large effect on attitude and intention to purchase online. Moreover, Perceived Usefulness has a small effect on attitude and large effect on intention to purchase online. Prior online purchase experience has a large effect on attitude and no effect on intention to purchase. Value of each latent variable is greater than zero which indicates predictive relevance of the constructs. Overall, the proposed study model is best fit with study objectives and hypotheses. 
Discriminant validity: Fornell-Larcker Criterion

Table 4: Discriminant Validity- Fornell-Larcker Criterian

\begin{tabular}{|c|lccccc|}
\hline SL. No. & \multicolumn{1}{|c}{ Constructs } & 1 & 2 & 3 & 4 & 5 \\
\hline \multirow{3}{*}{1} & Attitude & 0.84 & & & & \\
& & 0 & & & & \\
2 & Intention to Purchase Online & 0.78 & 0.84 & & & \\
& & 6 & 7 & & & \\
3 & Perceived Ease of Use & 0.67 & 0.75 & 0.85 & & \\
& & 6 & 2 & 8 & & \\
4 & Perceived Usefulness & 0.65 & 0.74 & 0.71 & 0.80 & \\
& & 3 & 3 & 5 & 2 & \\
5 & Prior Online Purchase Experience & 0.57 & 0.66 & 0.60 & 0.75 & \\
& & 7 & 7 & 8 & 6 & 0.928 \\
\hline
\end{tabular}

*The diagonal are the square root of the AVE (in bold) of the latent variables and indicates the highest in any column or raw

The table 4 above claims to test discriminant validity for evaluating the model using the Fornell-Larcker criteria. Furthermore, within a spectrum of 0.802-0.928, the square root of the AVE (in bold) of all variables represents the largest. As a result, it is understandable that discriminant validity is maintained between variables and is recognised for this study's predictable model.

\section{Structural Model Assessment}

Figure 2 depicts the structural model assessment. The bootstrapping procedure with a sample size of 500 was also used to calculate the $t$-values and $R$ square. 


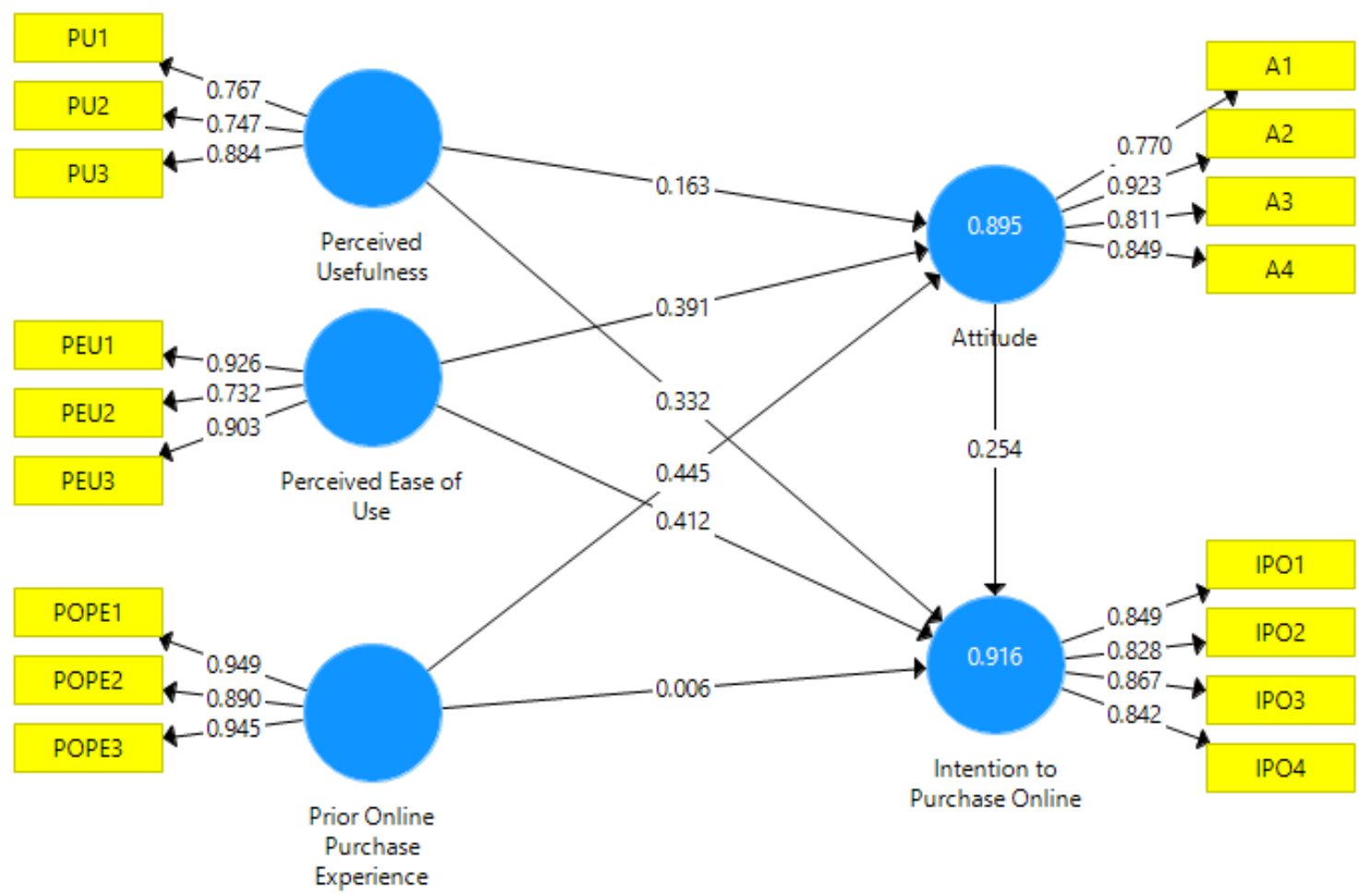

Figure 2: Standardized results of SEM calculations

\section{Hypotheses Testing}

Table 5: Result of Direct and Indirect Effect Hypotheses

\begin{tabular}{|c|l|c|c|c|c|c|}
\hline Hypotheses & \multicolumn{1}{|c|}{ Relationship } & $\begin{array}{c}\text { Std } \\
\text { Beta }\end{array}$ & $\begin{array}{c}\text { Std } \\
\text { Error }\end{array}$ & $\begin{array}{c}\text { t- } \\
\text { value }\end{array}$ & $\begin{array}{c}\mathbf{p}- \\
\text { value }\end{array}$ & Decision \\
\hline H1 & $\begin{array}{l}\text { Perceived Usefulness } \rightarrow \text { Intention to } \\
\text { Purchase Online }\end{array}$ & 0.334 & 0.071 & 4.706 & 0.000 & Supported \\
\hline H2 & $\begin{array}{l}\text { Perceived Ease of Use } \rightarrow \text { Intention to } \\
\text { Purchase Online }\end{array}$ & 0.415 & 0.078 & 5.311 & 0.000 & Supported \\
\hline H3 & $\begin{array}{l}\text { Prior Online Purchase Experience } \rightarrow \\
\text { Intention to Purchase }\end{array}$ & & & & & \\
\hline H4 & Perceived Usefulness $\rightarrow$ Attitude $\rightarrow$ IPO & 0.040 & 0.076 & 0.081 & 0.935 & Rejected \\
\hline H5 & Perceived Ease of Use $\rightarrow$ Attitude $\rightarrow$ IPO & 0.098 & 0.048 & 2.076 & 0.100 & Rejected \\
\hline H6 & $\begin{array}{l}\text { Prior Online Purchase Experience } \\
\text { HAttitude } \rightarrow \text { IPO }\end{array}$ & 0.118 & 0.054 & 2.103 & 0.036 & Supported \\
\hline
\end{tabular}

IPO: Intention to Purchase Online

Table 5 displays the outcomes of the hypothesis testing using SEM. To begin, researchers hypothesize a positive and significant relationship between individuals' perceived usefulness and their intention to purchase online. According to Table 5, there is a positive and significant association between an individual's perceived usefulness and their intention to purchase online $(=0.334, t=4.706, p 0.001)$. As a result, hypothesis 1 is admitted. Second, the researchers hypothesize that there is a positive and significant relationship between an 
individual's perceived usefulness and their intention to purchase online. As seen in Table 5, a positive and significant relationship found between individual's perceived usefulness and their intention to purchase online $(\beta=0.415, t=5.311, p<0.001)$. So, hypothesis 2 is accepted. Thirdly, researchers hypothesize that there is a positive and significant association between individual's prior online purchase experience and their intention to purchase online. As seen in Table 5, a positive and significant relationship found between individual's prior online purchase experience and their intention to purchase online $(\beta=0.002, t=0.081, p>0.05)$. So, hypothesis 3 is rejected.

Furthermore, fourthly, researchers hypothesize that attitude mediates the relationship between individual's perceived usefulness and their intention to purchase online. As seen in Table 5, researchers found that attitude mediates the relationship between individual's perceived usefulness and their intention to purchase online $(\beta=0.040, t=1.649, p>0.05)$. Therefore, hypothesis 4 is rejected. Fifthly, researchers hypothesize that attitude mediates the relationship between individual's perceived ease of use and their intention to purchase online. As seen in Table 5, researchers found that attitude mediates the relationship between individual's perceived ease of use and their intention to purchase online $(\beta=0.098, t=2.076$, $p<0.001$ ). Therefore, hypothesis 5 is accepted. Sixthly, researchers hypothesize that perceived risk mediates the relationship between individual's prior online purchase experience and their intention to purchase. As seen in Table 5, researchers found that attitude mediates the relationship between individual's prior online purchase experience and their intention to purchase online $(\beta=0.118, t=2.103, p<0.001)$. Therefore, hypothesis 6 is accepted.

\section{Conclusion}

The shopping propensity for buyers varies through e-computing power. Particularly in the world epidemic (COVID-19), particularly today's young people, custodians no longer depend entirely on the materials required to take their purchasing decision. This research reveals that the perceived confidence is related to the desire of the customer to buy online. This suggests that changes in the confidence felt by people can affect their intention to purchase online. Moreover, a positive and significant relationship is also found between individual's perceived usefulness and their online purchase intention, that means any change in individual's perceived usefulness will affect their online purchase intention. Furthermore, there is a positive and significant relationship between individual's prior online purchase experience and their online purchase intention. Besides, this study claims that attitude mediates the relationship between individual's perceived ease of use and prior online purchase experience with their intention to purchase. That means any changes in attitude will ultimately affect the relationship between perceived ease of use and prior online purchase experience with their intention to purchase online.

The findings further enhance the need to boost the consistency, confidence and empathy of the seller's website in order to increase their online buying intentions. Strengthening competition also means that the website quality service provider can pay more attention by enhancing the accessibility, design and quality of information on the site. This is because these considerations will influence the decision to buy online. When every disease strikes the planet, these online shops act like a miracle. The younger generations are keen to shop online after the COVID-19 epidemic. This time, however, shoppers should pay more attention to provide consumers with better services. Another important thing to focus on is the consumer partnership, which would broaden the customer's sense of compassion. The service provider 
must seek ways in which customer confidence and perceived utility are improved in their customer relationship management (CRM). Providing knowledgeable, outstanding and effective products and services will enhance consumer confidence. In order to establish and maintain a two-way connection to increase customer's online buying intention, service providers then have to restructure their e-CRM strategy. Because prior online acquisitions play an important part in influencing online acquisition intentions; service providers should consolidate digital website operations within the Business to Consumer interface contacts, which would in the end, inspire young generation to purchase goods from online shops over and over again.

\section{Limitations and Future Studies}

This research, like many other studies, has its limitations. Since the report only focused on young generation purchasers from the metropolitan region of Kuala Lumpur in Malaysia, this study only used empirical data to explore the research objectives. As a result, the study's findings do not have a comprehensive picture of the views of today's youth. Future studies could increase the sample size and collect data from different areas of Bangladesh, including rural areas. Furthermore, prospective researchers are strongly advised to broaden their research on Generation $Y$ in order to perceive more outcomes. Future research may also reveal ways for online sellers to develop and boost their credibility, as well as their capabilities. Future research may include the moderating influences of occupation and personality characteristics in the model to see how moderating variables affect the interaction between the independent and dependent variables.

\section{References}

Abdullah, D., Jayaraman, K., Shariff, D. N., Bahari, K. A., \& Nor, N. M. (2017). The effects of perceived interactivity, perceived ease of use and perceived usefulness on online hotel booking intention: A conceptual framework. International Academic Research Journal of Social Science, 3(1), 16-23.

Akar, E., \& Nasir, V. A. (2015). A review of literature on consumers' online purchase intentions. Journal of Customer Behaviour, 14(3), 215-233.

Alavi, S. A., Rezaei, S., Valaei, N., \& Ismail, W. K. (2016). Examining shopping mall consumer decision-making styles, satisfaction and purchase intention. The International Review of Retail, Distribution and Consumer Research, 26(3), 272-303.

Altawallbeh, M., Soon, F., Thiam, W., \& Alshourah, S. (2015). Mediating Role of Attitude, Subjective Norm and Perceived Behavioural Control in the Relationships between Their Respective Salient Beliefs and Behavioural Intention to Adopt E-Learning among Instructors in Jordanian Universities. Journal of Education and Practice, 6(11), 152-159.

Amin, M., Rezaei, S., and Abolghasemi, M. (2014), "User satisfaction with mobile websites: the impact of perceived usefulness (PU), perceived ease of use (PEOU) and trust", Nankai Business Review International, Vol. 5 No. 3, pp. 258274. https://doi.org/10.1108/NBRI-01-2014-0005.

Ashraf, A. R., Thongpapanl, N. T., \& Spyropoulou, S. (2016). The connection and disconnection between e-commerce businesses and their customers: Exploring the role of engagement, perceived usefulness, and perceived ease-of-use. Electronic Commerce Research and Applications, 20, 69-86. 
Balakrishnan, J., \& Griffiths, M. D. (2018). Loyalty towards online games, gaming addiction, and purchase intention towards online mobile in-game features. Computers in Human Behavior, 87, 238-246.

Bashir, M. A., Ali, M. H., Wai, L. M., Hossain, M. I., \& Rahaman, M. S. (2020). Mediating Effect of Customer Perceived Value on the Relationship between Service Quality and Customer Satisfaction of E-Banking in Bangladesh. International Journal of Advanced Science and Technology. Vol. 29, No. 2, pp. $3590-3606$

Bhattacharjee, A. M. I. T. A. B., Polas, M. R. H., \& Rahman, M. L. (2018). Challenges and prospects of tourism in Cox's bazar: An empirical study. Journal of Business and Technology (Dhaka), 13, 63-82.

Bhattacharjee, A., Polas, M.R.H., Ahmed, M., and Eshita, K.F. (2020). "Alternative Concern on the Remittance Increases Investments and Financial Sustainability", IIUB Studies, A Multidisciplinary Research Journal, Vol. 2, No.1, pp. 29-46.

Bonn, M. A., Kim, W. G., Kang, S., \& Cho, M. (2016). Purchasing wine online: The effects of social influence, perceived usefulness, perceived ease of use, and wine involvement. Journal of Hospitality Marketing \& Management, 25(7), 841-869.

Chang, W., \& Chao, R. F. (2018). The Impact of Shopping Values on Intention of Online Travel purchase for Mature Consumers: a Mediated Moderation Model. Journal of Tourism and Hospitality Management, 6(1), 92-99.

Chi, T. (2018). Mobile commerce website success: Antecedents of consumer satisfaction and purchase intention. Journal of Internet Commerce, 17(3), 189-215.

Cho, Y. C., \& Sagynov, E. (2015). Exploring factors that affect usefulness, ease of use, trust, and purchase intention in the online environment. International Journal of Management \& Information Systems (IJMIS), 19(1), 21-36.

Cohen, J. (1988). Statistical power analysis for the behavioural sciences, 2nd edn.(Hillsdale, NJ: L. Erlbaum Associates).

Dapas, C. C., Sitorus, T., Purwanto, E., \& Ihalauw, J. J. (2019). The effect of service quality and website quality of Zalora. com on purchase decision as mediated by purchase intention. Calitatea, 20(169), 87-92.

De Cock, R., Vangeel, J., Klein, A., Minotte, P., Rosas, O., \& Meerkerk, G. J. (2014). Compulsive use of social networking sites in Belgium: Prevalence, profile, and the role of attitude toward work and school. Cyberpsychology, Behavior, and Social Networking, 17(3), 166171.

De la Llave, M. A., López, F. A., \& Angulo, A. (2019). The impact of geographical factors on churn prediction: an application to an insurance company in Madrid's urban area. Scandinavian Actuarial Journal, 2019(3), 188-203.

Dedeke, A. N. (2016). Travel web-site design: Information task-fit, service quality and purchase intention. Tourism management, 54, 541-554.

Dhahak, K., \& Huseynov, F. (2020). The Influence of Gamification on Online Consumers' Attitude and Intention to Purchase Fast Moving Consumer Goods. Business and Economics Research Journal, 11(3), 769-791.

Driediger, F., \& Bhatiasevi, V. (2019). Online grocery shopping in Thailand: Consumer acceptance and usage behavior. Journal of Retailing and Consumer Services, 48, 224237.

Escobar-Rodríguez, T., \& Bonsón-Fernández, R. (2017). Analysing online purchase intention in Spain: fashion e-commerce. Information Systems and e-Business Management, 15(3), 599-622. 
Fazal-e-Hasan, S. M., Ahmadi, H., Mortimer, G., Grimmer, M., \& Kelly, L. (2018). Examining the role of consumer hope in explaining the impact of perceived brand value on customer-brand relationship outcomes in an online retailing environment. Journal of Retailing and Consumer Services, 41, 101-111.

Fraustino, J. D., Lee, J. Y., Lee, S. Y., \& Ahn, H. (2018). Effects of 360 video on attitudes toward disaster communication: Mediating and moderating roles of spatial presence and prior disaster media involvement. Public relations review, 44(3), 331-341.

Fu, S., Yan, Q., \& Feng, G. C. (2018). Who will attract you? Similarity effect among users on online purchase intention of movie tickets in the social shopping context. International Journal of Information Management, 40, 88-102.

Ghouri, A. M., Haq, M. A. U., \& Naveed, R. K. (2017). Customer perception on online purchase intention: the impact of online shopping orientations on online buying intention. The Eurasia Proceedings of Science Technology Engineering and Mathematics, (1), 76-82.

Hameed, F., \& Qayyum, A. (2018). Determinants of behavioral intention towards mobile learning in Pakistan: Mediating role of attitude. Business and Economic Review, 10(1), 33-61.

Hanjaya, M., Kenny, K., \& Gunawan, F. (2019). Understanding factors influencing consumers online purchase intention via mobile app: perceived ease of use, perceived usefulness, system quality, information quality, and service quality. Marketing Instytucji Naukowych i Badawczych, (2 (32)), 175-206.

Hansen, J. M., Saridakis, G., \& Benson, V. (2018). Risk, trust, and the interaction of perceived ease of use and behavioral control in predicting consumers' use of social media for transactions. Computers in Human Behavior, 80, 197-206.

Hess, T. J., McNab, A. L., \& Basoglu, K. A. (2014). Reliability generalization of perceived ease of use, perceived usefulness, and behavioral intentions. Mis Quarterly, 38(1), 1-28.

Hossain, A., Jamil, A. A., \& Rahman, M. M. (2018). Exploring the key factors influencing consumers' intention, satisfaction and loyalty towards online purchase in Bangladesh. International Journal of Economics and Financial Research, 4(7), 214-225.

Hossain, M. I., Limon, N., Amin, M. T., \& Asheq, A. S. (2018). Work Life Balance Trends: A Study on Malaysian GenerationY Bankers. IOSR Journal of Business and Management, 20 (9), 01-09.

Hossain, M. I., Polas , M. R. H., Rahman, M. M., Islam, T., \& Jamadar, Y. (2020). An Exploration of COVID-19 Pandemic and its Consequences on FMCG Industry in Bangladesh. Journal of Management Info, 7(3), 145-155. https://doi.org/10.31580/jmi.v7i3.1484

Hossain, S. A., Bao, Y., Hasan, N., \& Islam, M. F. (2020). Perception and prediction of intention to use online banking systems: An empirical study using extended TAM. International Journal of Research in Business and Social Science (2147-4478), 9(1), 112-116.

Joo, Y. J., Park, S., \& Lim, E. (2018). Factors influencing preservice teachers' intention to use technology: TPACK, teacher self-efficacy, and technology acceptance model. Journal of Educational Technology \& Society, 21(3), 48-59.

Kaushal, S. K., \& Kumar, R. (2016). Influence of Attitude Towards Advertisement on Purchase Intention: Exploring the Mediating Role of Attitude Towards Brand Using SEM Approach. IUP Journal of Marketing Management, 15(4).

Khaled, A. S., Ahmed, S., Tabash, M. I., Al-Homaidi, E. A., \& Hossain, M. I.(2019). The Impact of Technological and Marketing Innovations on Retailing Industry: Evidence of India. Journal of Reviews on Global Economics, 8, 948-957 
Koththagoda, K. C., \& Herath, H. M. R. P. (2018). Factors influencing online purchasing intention: The mediation role of consumer attitude. Journal of Marketing and Consumer Research, 42, 66-74.

Kwol, V. S., Eluwole, K. K., Avci, T., \& Lasisi, T. T. (2020). Another look into the Knowledge Attitude Practice (KAP) model for food control: An investigation of the mediating role of food handlers' attitudes. Food Control, 110, 107025.

Lee, E. Y., Lee, S. B., \& Jeon, Y. J. J. (2017). Factors influencing the behavioral intention to use food delivery apps. Social Behavior and Personality: an international journal, 45(9), 1461-1473.

Lee, J., \& Lee, J. N. (2015). How purchase intention consummates purchase behaviour: the stochastic nature of product valuation in electronic commerce. Behaviour \& Information Technology, 34(1), 57-68.

Lim, Y. J., Osman, A., Salahuddin, S. N., Romle, A. R., \& Abdullah, S. (2016). Factors influencing online shopping behavior: the mediating role of purchase intention. Procedia economics and finance, 35, 401-410.

Ling, K. C., Chai, L. T., \& Piew, T. H. (2010). The effects of shopping orientations, online trust and prior online purchase experience toward customers' online purchase intention. International business research, 3(3), 63.

López-Bonilla, L. M., \& López-Bonilla, J. M. (2017). Explaining the discrepancy in the mediating role of attitude in the TAM. British Journal of Educational Technology, 48(4), 940-949.

Ma, Y. J., Gam, H. J., \& Banning, J. (2017). Perceived ease of use and usefulness of sustainability labels on apparel products: application of the technology acceptance model. Fashion and Textiles, 4(1), 1-20.

Mohmed, A. S. I., Azizan, N. B., \& Jali, M. Z. (2016). Investigating Customer's Intention to Purchase Online Based on Sharia Perspective. Res. Electron. Commer. Front., 3, 7-17.

Mohseni, S., Jayashree, S., Rezaei, S., Kasim, A., \& Okumus, F. (2018). Attracting tourists to travel companies' websites: the structural relationship between website brand, personal value, shopping experience, perceived risk and purchase intention. Current Issues in Tourism, 21(6), 616-645.

Moreno, F. M., Lafuente, J. G., Carreón, F. Á., \& Moreno, S. M. (2017). The characterization of the millennials and their buying behavior. International Journal of Marketing Studies, 9(5), 135-144.

Moslehpour, M., Pham, V. K., Wong, W. K., \& Bilgiçli, İ. (2018). e-purchase intention of Taiwanese consumers: Sustainable mediation of perceived usefulness and perceived ease of use. Sustainability, 10(1), 234.

Nam, S. A., Cho, Y. R., \& Noh, S. S. (2019). Efficacy of a mindfulness-based intervention for smartphone overuse, functional impairment, and mental health among undergraduate students at risk for smartphone addiction and the mediating role of selfregulation. Korean Journal of Clinical Psychology, 38(1), 29-44.

Oghazi, P., Karlsson, S., Hellström, D., \& Hjort, K. (2018). Online purchase return policy leniency and purchase decision: Mediating role of consumer trust. Journal of Retailing and Consumer Services, 41, 190-200.

Ogiemwonyi, O., Harun, A. B., Alam, M. N., Karim, A. M., Tabash, M. I., Hossain, M. I., \& Ojuolape, M. A. (2020). Green product as a means of expressing green behaviour: A cross-cultural empirical evidence from Malaysia and Nigeria. Environmental Technology \& Innovation, 20, 101055. 
Ozturk, A. B., Bilgihan, A., Nusair, K., \& Okumus, F. (2016). What keeps the mobile hotel booking users loyal? Investigating the roles of self-efficacy, compatibility, perceived ease of use, and perceived convenience. International Journal of Information Management, 36(6), 1350-1359.

Polas, M. R. H., \& Jahanshahi, A. (2020). The effects of individual characteristics on women intention to become social entrepreneurs?. Journal of Public Affairs, e2204. https://doi.org/10.1002/pa.2204

Polas, M. R. H., \& Raju, V. (2021). Technology and entrepreneurial marketing decisions during COVID-19. Global Journal of Flexible Systems Management, 22(2), 95-112.

Polas, M. R. H., Jahanshahi, A. A., \& Rahman, M. L. (2018a). Islamic branding as a tool for customer retention: Antecedents and consequences of islamic brand loyalty. International Journal of Islamic Marketing and Branding, 3(1), 1-14.

Polas, M. R. H., Rahman, M. M., Miah, M. A., \& Hayash, M. M. A. (2018b). The impact of waiting time towards customers satisfaction in fast food establishments: Evidence from Bangladesh. IOSR Journal of Business and Management, 20(5), 11-21.

Polas, M. R. H., Raju, V., Hossen, S. M., Karim, A. M., \& Tabash, M. I. (2020). Customer's revisit intention: Empirical evidence on Gen-Z from Bangladesh towards halal restaurants. Journal of Public Affairs, e2572. https://doi.org/10.1002/pa.2572

Polas, M. R. H., Reza, M. M. U., \& Rowza, S. (2017). Role of advertising and service quality on tourism development in Bangladesh. IOSR Journal of Business and Management, 19(9), 77-86.

Polas, M. R. H., Raju, V., Muhibbullah, M., and Tabash, M. I. (2021). Rural women characteristics and sustainable entrepreneurial intention: a road to economic growth in Bangladesh, Journal of Enterprising Communities: People and Places in the Global Economy. https://doi.org/10.1108/JEC-10-2020-0183

Ponte, E. B., Carvajal-Trujillo, E., \& Escobar-Rodríguez, T. (2015). Influence of trust and perceived value on the intention to purchase travel online: Integrating the effects of assurance on trust antecedents. Tourism Management, 47, 286-302.

Rafsandjani, R. F. (2018). Analyzing the effect of trust and perceived value on purchase intention (case study of Shopee). MEC-J (Management and Economics Journal), 2(1), 65 78.

Rajesh, R. (2018). Evaluating the factors influencing online shopping and its consumer satisfaction in Pune Area. PEOPLE: International Journal of Social Sciences, 4(1), 54-76.

Raza, S. A., Umer, A., \& Shah, N. (2017). New determinants of ease of use and perceived usefulness for mobile banking adoption. International Journal of Electronic Customer Relationship Management, 11(1), 44-65.

Redondo, I., \& Aznar, G. (2018). To use or not to use ad blockers? The roles of knowledge of ad blockers and attitude toward online advertising. Telematics and Informatics, 35(6), 1607-1616.

Rehman, S. U., Bhatti, A., Mohamed, R., \& Ayoup, H. (2019). The moderating role of trust and commitment between consumer purchase intention and online shopping behavior in the context of Pakistan. Journal of Global Entrepreneurship Research, 9(1), 1-25.

San, O. T., Teh, B. H., Kasbun, N. F., Mahroeian, H., Hossain, M. I. (2020). Electronic Commerce Adoption among Malaysian SMEs. Journal of Critical Reviews. 7(19), 555565. 
See-To, E. W., \& Ho, K. K. (2014). Value co-creation and purchase intention in social network sites: The role of electronic Word-of-Mouth and trust-A theoretical analysis. Computers in Human Behavior, 31, 182-189.

Septiani, R., Handayani, P. W., \& Azzahro, F. (2017). Factors that affecting behavioral intention in online transportation service: Case study of GO-JEK. Procedia Computer Science, 124, 504-512.

Shaouf, A., Lü, K., \& Li, X. (2016). The effect of web advertising visual design on online purchase intention: An examination across gender. Computers in Human Behavior, 60, 622-634.

Siamagka, N. T., Christodoulides, G., \& Michaelidou, N. (2016). The Impact of Comparative Affective States on Online Brand Perceptions: The Moderating Role of Cultural Dimensions. In Let's Get Engaged! Crossing the Threshold of Marketing's Engagement Era (pp. 59-62). Springer, Cham.

Silva, A. T., Moro, S., Rita, P., \& Cortez, P. (2018). Unveiling the features of successful eBay smartphone sellers. Journal of Retailing and Consumer Services, 43, 311-324.

Suleman, D., \& Zuniarti, I. (2019). Consumer Decisions toward Fashion Product Shopping in Indonesia: The effects of Attitude, Perception of Ease of Use, Usefulness, and Trust. Management Dynamics in the Knowledge Economy, 7(2), 133-146.

Van der Heijden, H., Verhagen, T., \& Creemers, M. (2003). Understanding online purchase intentions: contributions from technology and trust perspectives. European journal of information systems, 12(1), 41-48.

Vazquez, D., and Xu, X. (2009), "Investigating linkages between online purchase behaviour variables", International Journal of Retail \& Distribution Management, Vol. 37 No. 5, pp. 408-419. https://doi.org/10.1108/09590550910954900

Visinescu, L. L., Sidorova, A., Jones, M. C., \& Prybutok, V. R. (2015). The influence of website dimensionality on customer experiences, perceptions and behavioral intentions: An exploration of 2D vs. 3D web design. Information \& Management, 52(1), 1-17.

Wan, C., \& Shen, G. Q. (2015). Encouraging the use of urban green space: The mediating role of attitude, perceived usefulness and perceived behavioural control. Habitat International, 50, 130-139.

Wang, Y., Wang, S., Wang, J., Wei, J., \& Wang, C. (2020). An empirical study of consumers' intention to use ride-sharing services: using an extended technology acceptance model. Transportation, 47(1), 397-415.

Wu, H. C., \& Cheng, C. C. (2018). What drives experiential loyalty toward smart restaurants? The case study of KFC in Beijing. Journal of Hospitality Marketing \& Management, 27(2), 151-177.

Yahia, I. B., Al-Neama, N., \& Kerbache, L. (2018). Investigating the drivers for social commerce in social media platforms: Importance of trust, social support and the platform perceived usage. Journal of Retailing and Consumer Services, 41, 11-19.

Yang, H., Yu, J., Zo, H., \& Choi, M. (2016). User acceptance of wearable devices: An extended perspective of perceived value. Telematics and Informatics, 33(2), 256-269.

Yulianita, Y. (2018). Comparison of generation $x$ and y: Perceived usefulness, perceived ease of use, and subjective norms on purchase intention in e-commerce. Jurnal Komunikasi Indonesia, 140-152.

Zhang, M., Luo, M., Nie, R., \& Zhang, Y. (2017). Technical attributes, health attribute, consumer attributes and their roles in adoption intention of healthcare wearable technology. International journal of medical informatics, 108, 97-109. 